\title{
DESIGNING TOURISM IDENTITY COMMUNICATION IN SATUN UNESCO GLOBAL GEOPARK
}

\author{
Budsarin NANTAKAT \\ Walailak University, School of Informatics, 222 Thasala district, Nakhon Si Thammarat 80160, Thailand, e-mail: budsarin.na@wu.ac.th \\ Varunyu VORACHART \\ Walailak University, School of Informatics, 222 Thasala district, Nakhon Si Thammarat 80160, Thailand, e-mail: varunyu.vo@wu.ac.th
}

\author{
Citation: Nantakat, B., \& Vorachart, V. (2021). DESIGNING TOURISM IDENTITY COMMUNICATION IN SATUN UNESCO \\ GLOBAL GEOPARK. GeoJournal of Tourism and Geosites, 35(2), 275-281. https://doi.org/10.30892/gtg.35202-648
}

\begin{abstract}
Satun Geopark, located in the south of Thailand, was recently designated as UNESCO Global Geopark in 2018. The geopark is well known for its abundance and variety of Paleozoic fossils with many outstanding geological tourist sites, incl uding specular karst landscapes, stunning caves, and remarkable sea caves. To promote Satun Geopark as tourist destination, its tourism identities must be communicated to wider audiences. This will convey the unique value of local communities to draw attention to new visitors and attract existing ones for a revisit. This research conducted in-depth interviews with community leaders and surveyed on-site signage systems to find out an improvement on tourism identity communication. The design of identity mascot was proposed as a new tool to communicate its identity with visitors in various channels.
\end{abstract}

Key words: Tourism, Tourism Identity, Identity Communication, Mascots, Satun UNESCO Global Geopark

$* * * * *$

\section{INTRODUCTION}

Tourism industry plays a very important role to Thailand's economic growth. In 2019, there were 39.80 million foreign tourists visiting the country and generating revenues of 62.29 billion USD, compared to 58.07 billion USD in $2018 .{ }^{1}$ Tourism is now becoming an economic instrument that Thai government emphasize on because tourism is important to generate income for country development. Income from the tourism is among the top figures and, the most importance, is distributed directly into the locals. Therefore, local administrations and related government agencies created policies and plans for tourism development and promotion. The key government agency responsible for tourism promotion and support throughout the country since 1960 is the Tourism Authority of Thailand (TAT) (Tourism Authority of Thailand, 2020). One of the major promotion plans initiated by TAT in 2018 was marketing tourism on less-visited minor city, so called Muang Roung in Thai language, to spread out the number of tourists according to the potentials of each area (Tourism Authority of Thailand, 2020). The project, named Muang Roung, must try, was set up for tourists who truly appreciate the uniqueness of each local area.

Satun province locates in the south of Thailand, on the side of Andaman Sea in the Malay Peninsula. It is a secondary city that is distinguished by its primeval geology, unique ecology, biodiversity, and rich culture. This significant area has been designated as Satun UNESCO Global Geopark recently in 2018 (Thungprue et al., 2015). It is the first UNESCO Global Geopark of Thailand and is located approximately $50 \mathrm{~km}$. north of Malaysia's Langkawi UNESCO Global Geopark, that is the first global geopark in Southeast Asia since 2007 (Mohd Yusof et al., 2019). With the area of 2,597.21 km ${ }^{2}$, the geopark covers four districts, namely Thungwa, La-ngu, Manang, and part of Mueang Satun district, as shown in Table 1.

Table 1. List of notable geosites, with number notations as shown in Figure 1

in four districts of Satun Province that constituted Satun UNESCO Global Geopark

\begin{tabular}{|c|c|c|}
\hline District Name & $\begin{array}{l}\text { Number of Geosites in } \\
\text { Satun Global Geopark }\end{array}$ & Notable Geosites \\
\hline Thung Wa & 8 & Tharn Plew Waterfall, \\
\hline Manang & 4 & 9 Phu Pha Petch Cave, $\quad$ 12 Chet Khot Cave, $\quad$ (11)Pa Phon Lapies \\
\hline La-ngu & 10 & Prasat Hin Punyod, 27) Lidi Lek Island, 26)Kho To Ngai Geological Time Boundary \\
\hline Mueang Satun & 6 & 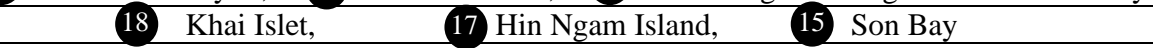 \\
\hline
\end{tabular}

It includes one wildlife sanctuary and two national parks, i.e. Khao Banthat Wildlife Sanctuary, Petra Islands National Park and Tarutao National Park, respectively. It consists of 28 geological sites (geosites), as illustrated in Figure 1, and more than 16 tourist attractions. The outstanding point of interest in the geopark is marine-life fossils which were found diversely and continuously in all six geologic periods of Paleozoic Era, dated back to approximately 548 - 250 million years ago. The oldest Trilobite, a group of extinct marine arthropods, in Southeast Asia has also been found in the geopark. In addition, the region is notable for the hierarchy of rock layer system, ancient bacterial in rock-like structures or Stromatolite as well as the worldclass beautiful limestone landscape. In addition to karst topology in the area that creates stunning geosites such as caves, sea

\footnotetext{
${ }^{*}$ Corresponding author

${ }^{1}$ Economic Tourism and Sports Division, Ministry of Tourism and Sports, Thailand
} 
caves and lapies (Ruban, 2018), this area is important in linking ancient sites, multiple cultures including Buddhism and Islam, and the way of life among the local ethnic groups, for example the Mani or Maniq, the Moken and the Urak Lawoi sea gypsies (Thungprue et al., 2015). Community leaders and local government in Satun Province collaboratively promoted the geological areas in Satun from the provincial level to the international level until it was designated Satun UNESCO Global Geopark in 2018. This resulted to more income to the local communities and improved the overall economy of the province. The revenue from tourism in Satun province in 2018 was 9,100 million Baht, increasing $11.41 \%$ from 8,168 million Baht in $2017^{2}$. Satun Province is one of the minor cities that have potential in tourism growth.

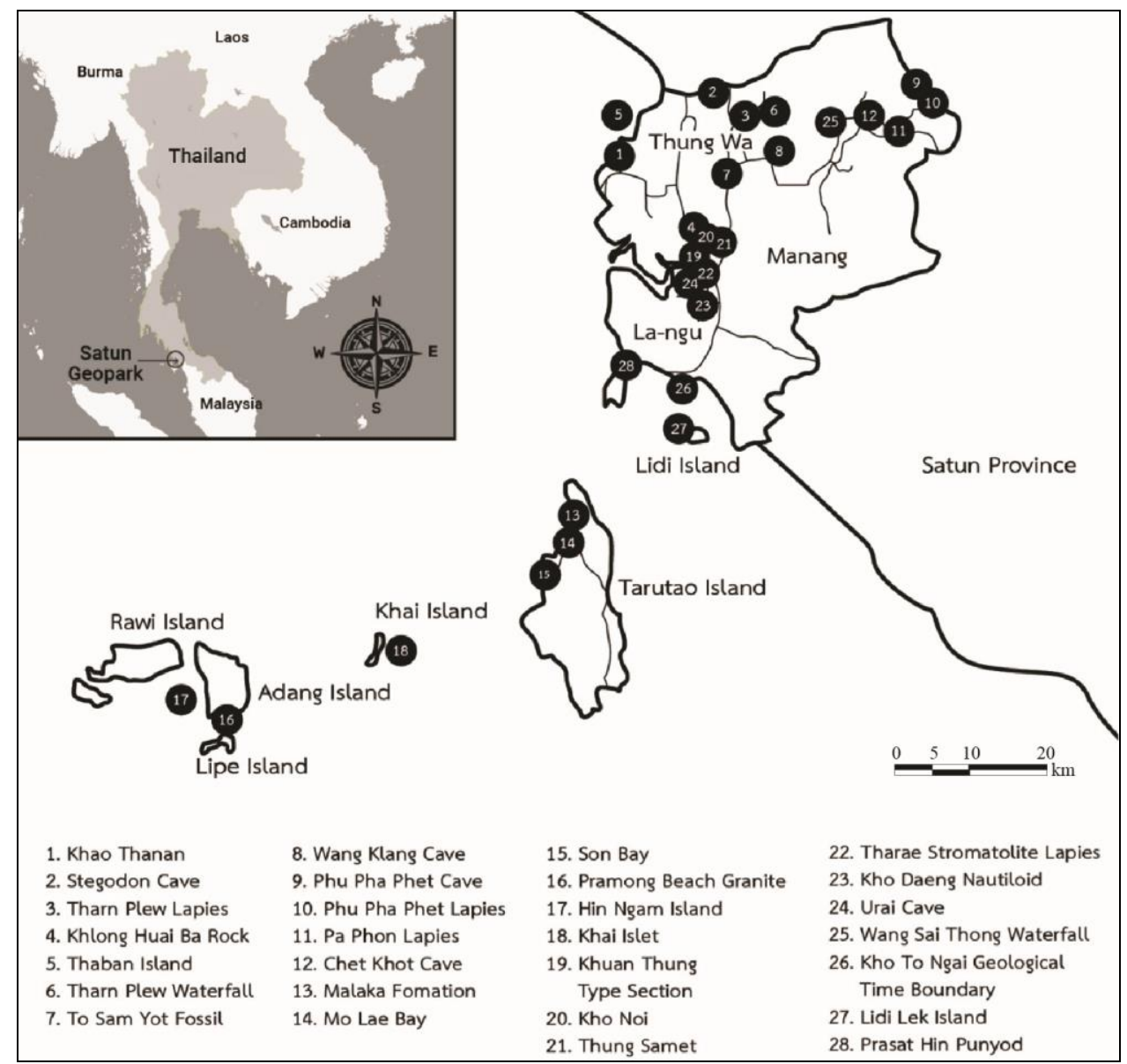

Figure 1. Satun UNESCO Global Geopark locates in Satun Province, The geopark covers four districts, namely Thung Wa, Manang, La-ngu and part of Mueang Satun District
In accordance with Muang Roung, must try project, Tourism Council of $\mathrm{T}$ hailand (TCT) set up a subcommittee on domestic tourism promotion with its main mission to promote the development of tourist attractions, communities, products for tourists, and tourist routes with identities. TCT is an assembly of private sectors in tourism industry with working groups in each province to work together with TAT in local areas. It helps restore, develop, and conserve tourist attractions in natural, historical, and cultural sites to meet the industry standard. It also helps extract the identity in each community for public presentation and develop communication techniques for storytelling to bring out charms and values of each region. The main goal is to reduce inequalities, create balances in tourism, and distribute income to local communities. One of TCT initiatives in southern provinces, that are situated between Gulf of Thailand on the east and Andaman Sea on the west, is to "lure more tourists from the beach to villages" to reduce overloading in popular tourism areas and create more sustainability for the locals (Worrachaddejchai, 2020). There are various models and approaches to convince and persuade tourists to visit unfamiliar destinations. With trends in ecological tourism, the community-based tourism (CBT), where traveling services are supplied by residents in local community with the benefits of both the community and travelers, is a promising idea to provide sustainability in TAT's second-tier city policy, especially in remote areas with unique natural landscape in Satun Geopark (Strydom et al., 2019) (Stoffelen, 2020). Communication strategy like storytelling or, specifically, geo-storytelling from the locals are excellent resources to motivate and engage visiting to a community (Pera, 2017) (Wolniewicz, 2019) (Górska-zabielska and Zabielski, 2019). In addition, city branding is a marketing strategy that helps position and distinguish a city from its competitors (Soltani et al., 2018) (Mastika and Nimran, 2020). Tourism identity of a region is a key for both strategies to communicate its branding to public.

To maintain the UNESCO Global Geopark status, Satun UNESCO Global Geopark is now preparing for the revalidation process from UNESCO. The process takes place every four years in each Global Geopark to examine its quality and performance (Henriques and Brilha, 2017). Satun UNESCO Global Geopark is about to submit the progress report in 2021 and get full revalidated by UNESCO in 2022. Therefore, the main goal of this research was to search for tourism identities of Satun UNESCO Global Geopark and propose the key findings as well as solutions, in terms of identity communication, to the director of Satun UNESCO Global Geopark for further consideration.

\section{MATERIAL AND METHODS}

Identity is a particular feature that makes someone or something stand out or be different from others. Therefore, identity communication means communication processes in which communities can tell themselves who we are and, optionally at the same time, tell others who they are. Tourism with local identity communicates interesting and distinct

\footnotetext{
${ }^{2}$ Satun Provincial Office, Thailand
} 
details in community that differs from others. It is one of the popular methods to attract tourists. Shifting behavior and expectations of tourists influence the choice of travel destination in various forms, regardless of the purpose of the tourism. $60 \%$ of travelers today think that the travel destination they are interested in must be a destination that indicates their identity (Chantub and Pocharee, 2016). Hence, a tourism identity is so important that most tourists are looking for to experience from a trip. Therefore, all stakeholders must be involved in determining a tourism identity in accordance with their local settings (Dhamabutra, 2019). Identity communication for tourism promotion communicates both inside and outside a community. On the one hand, communicating inside a community creates participation and pride in the community.

On the other hand, communicating outside the community creates the tourist attentions, encourages visitors to visit the community and helps tourists understand the tradition of the community (Chaiala and Ruengroj, 2016). Communication is vital in the development of a community. Tourism communication is the art of communicating to deliver compelling stories to help tourists understand and realize the importance of the community. Additionally, communication among community members led to the exchange of opinions to reflect the community identity more clearly (Chaiala and Ruengroj, 2016). An analysis of identity communication in Satun UNESCO Global Geopark through signboards in tourist sites is the key factor that leads to finding the identity strengths and to communicate and convey them to visitors. Developing the tourist sites in Satun UNESCO Global Geopark allows tourists to access information and obtain knowledge of the area. Identity communication is of importance because improvements of the sites are a part of preparation for revalidation and a progressive assessment of the UNESCO Global Geopark designation. One of the assessment indicators is that the Global Geopark must focus on informative and communicative purposes (Pásková and Zelenka, 2018) (UNESCO, n.d.). It must have easy-tounderstand information and communication about the site. If the community and local government develop a signage system with identity communication complying with UNESCO assessment indicators, it will be a major support for the continuation of this area as a UNESCO Global Geopark in a long run. The objectives of this research are to study the signage system presented in geosites of Satun UNESCO Global Geopark and propose methods for identity communication in Satun UNESCO Global Geopark through the signage system. This will benefit in participation and knowledge exchange among researchers in the project and the locals in both governmental and non-governmental agencies. This will lead to creation of knowledge and awareness in natural resource conservation to communicate with visitors in the geopark.

\section{Research Methods}

Two approaches of qualitative research were used as main methods to survey the existing signage systems throughout the geopark and search for improvements in better identity communication. One is interviewing with stakeholders in the local area. Another approach is observation and evaluation of the on-site signage systems in all 28 geosites. Note that all interview and on-site data were collected before the outbreak of COVID-19 pandemic in February 2020 and the prevention of inbound tourists entering the country that suddenly ceased the tourism activities for months.

Table 2. List of interview groups in all four districts covering Satun UNESCO Global Geopark

\begin{tabular}{|c|l|c|}
\hline District Name & \multicolumn{1}{|c|}{ Interview Group or Individual } & Group Activities \\
\hline Thung Wa & 1. Director of Satun Geopark / Chief Executive of Thung Wa Subdistrict Administrative Organization (SAO) & Administration \\
\hline & 2. Deputy Director of Satun Geopark (Tourism Service Division) & Administration \\
\hline & 3. Mor Khao Mor Khang Ling (tropical pitcher plants) Group & Tour (general sites) \\
\hline & 4. Stegodon Sea Cave Tour Guides & Geosite Tour \\
\hline & 5. Thung Wa Homestay Godon Community Enterprise & Homestay \\
\hline & 6. Tha-oi Natural Dye Community Enterprise & Natural Dyed Fabric \\
\hline & 7. Thung Wa Community Tourist Community Enterprise & Geosite Tour \\
\hline Manang & 1. Phu Pha Petch Tourism Community Group & Geosite Tour \\
\hline & 2. Phu Pha Petch Cave Tour Guides & Geosite Tour \\
\hline & 3. Deputy Director of Satun Geopark (Conservation and Development Division) / Deputy Chief & \multirow{2}{*}{ Administration } \\
\hline Administrator of Palm Pattana SAO & Geosite Tour \\
\hline La-ngu & Geosite Tour \\
\hline & 2. Bo Chast Luk Tourism Community Group Pun Yod Tour Guides & Batik Fabric \\
\hline & 3. Panya Batik Group & - \\
\hline Mueang Satun & & $-\dagger$ \\
\hline$\dagger$ No community group/enterprise in Mueang Satun District. All are private companies which are not in research focus
\end{tabular}

First, several in-depth interviews with 13 groups or individuals in four districts, as shown in Table 2, were conducted in 2019. Snowball sampling was used to determine a list of interview groups. Starting from the director of Satun Geopark, an interview subject suggests future subjects from his or her connections. Their opinions, needs, concerns and expectations were asked and later analyzed for the identities of each local geosite. The question topics include:

- General information of interviewed person/group.

- Notable geosite or tourist attraction, both tangible and intangible, in the area \& its uniqueness.

- Geographical and physical context in the community.

- Collaboration in the area/community.

- Behavior and needs of target visitors.

- How visitors \& the prospects get access to travel information.

- What is the existing means of travel/identity communication? (in terms of form, content, and design) 
- Required or improvement of travel/identity information for better communication in Satun UNESCO Global Geopark.

Second, the signage system in each geosite was evaluated as the main on-site communication channel to visitors. The assessment criteria of a signage system include size and number of signs, types and usefulness of information, convenience of information access, site identity, as well as safety and engagement of both Thai and international visito rs. In addition to the field data, academic documents, textbooks, magazine and internet articles were examined for best practices in tourism identity communication (Tölkes, 2018) (Ongkrutraksa, 2015) (Calori and Vanden-Eynden, 2015).

Data analysis from interview records and on-site evaluation were done in descriptive analysis. Then, the conclusions were drawn according to the process to find out the identities of Satun UNESCO Global Geopark. Subsequently, the prototype to demonstrate identity communication for the geopark is designed for further consideration from Satun Geopark committee in the preparation for UNESCO revalidation in 2022.

\section{Findings in Tourism identities}

Satun UNESCO Global Geopark has a unique identity in its geology of rock formations with fossils of ancient sea creatures as well as world-class beautiful limestone landscape in Andaman shore. This produces a wide range of natural tourism activities such as whitewater rafting, scuba diving, caving, waterfall, and beach excursions.

Each district in Satun UNESCO World Geopark also has different outstanding geological identities as follow:

- Thung Wa District is famous for eco-tourism and adventure traveling sites. The most remarkable geosite is Stegodon Sea Cave. It is a long limestone mountain cave that looks like a tunnel under the mountain. The exceptional findings in the cave are elephant and rhinoceros fossils in the Pleistocene period.

- Manang District contains numerous eco-tourism and adventure tourist sites. An outstanding geosite is Phu Pha Petch Cave. Its remarkable characteristic is a large limestone cave with beautiful stalactites and stalagmites. Inside the cave, fossils of bacteria (Stromatolite) and ancient sea ink (Nautiloid) were found. This is an indicator that the age of limestone area in Phu Pha Petch Cave is in the Ordovician period, or about 450 million years ago.

- La-ngu District is well-known for marine attractions and islands. An outstanding geosite is Prasat Hin Phan Yod. It is a primeval sea in the Paleozoic Era that is more than 540 million years old. In this area, the red sedimentary rocks formed in the Cambrian period and the gray limestones in the Ordovician period also can be found. These two evidences may lead to an assumption that this spot was the earliest ground of the region.

- Mueang Satun District is also well-known for marine attractions and islands. The outstanding geosite is Khai Island Coastal Arch. Here is a midpoint when sailing from Pak Bara Pier to Lipe Island. There is a pointed, steep cliff on the north of the island with a rocky arch on the beach. This location appears in the logo of Satun UNESCO Global Geopark with the theme shades of blue colors. Most of the rocks are sandstones with different cracking directions in their structure. The cracks commonly contain iron oxide which has higher corrosion resistance than underlying sandstones. Therefore, in some areas, a three-dimensional lattice structure of iron oxide was found because the underlying rocks were completely worn off.

Table 3. The summary of sign content in each geosites of Satun UNESCO Global Geopark

\begin{tabular}{|c|c|c|c|c|c|c|c|c|c|c|c|}
\hline \multirow[b]{2}{*}{ District name } & \multirow[b]{2}{*}{ Geosite Name } & \multirow[b]{2}{*}{$\begin{array}{c}\text { Number } \\
\text { of Signs }\end{array}$} & \multicolumn{5}{|c|}{ Types of Signage } & \multicolumn{3}{|c|}{ Language } & \multirow{2}{*}{$\begin{array}{l}\text { QR } \\
\text { Code }\end{array}$} \\
\hline & & & $\begin{array}{c}\text { Geopark } \\
\text { Map \& Info }\end{array}$ & \begin{tabular}{|c|} 
Geosite \\
Map \& Info
\end{tabular} & \begin{tabular}{|c|} 
specific \\
spot info
\end{tabular} & Quiz & Precautions & $\mathbf{T H}$ & $\mathbf{E N}$ & $\mathbf{C H}$ & \\
\hline \multirow[t]{5}{*}{ Thung Wa } & Stegodon Sea Cave & 9 & $\checkmark$ & $\checkmark$ & $\checkmark$ & & & $\checkmark$ & & & $\checkmark$ \\
\hline & Khao Thanan & 3 & $\checkmark$ & $\checkmark$ & & & & $\checkmark$ & $\checkmark$ & & \\
\hline & Tharn Plew Waterfall & 3 & $\checkmark$ & $\checkmark$ & & & & $\checkmark$ & & & \\
\hline & To Sam Yot Fossil & 3 & $\checkmark$ & $\checkmark$ & & & & $\checkmark$ & & & \\
\hline & \multicolumn{11}{|c|}{ No signage system: Tharn Plew Lapies, Khlong Huai Ba Rock, Wang Klang Cave, Thaban Island } \\
\hline \multirow[t]{4}{*}{ Manang } & Phu Pha Petch Cave & 6 & $\checkmark$ & $\checkmark$ & $\checkmark$ & $\checkmark$ & $\checkmark$ & $\checkmark$ & $\checkmark$ & & \\
\hline & Chet Khot Cave & 6 & $\checkmark$ & $\checkmark$ & $\checkmark$ & & & $\checkmark$ & $\checkmark$ & & \\
\hline & Phu Pha Petch Lapies & 6 & $\checkmark$ & $\checkmark$ & $\checkmark$ & & & $\checkmark$ & $\checkmark$ & & \\
\hline & Pa Phon Lapies & 3 & $\checkmark$ & $\checkmark$ & & & & $\checkmark$ & $\checkmark$ & & \\
\hline \multirow[t]{10}{*}{ La-ngu } & Urai Cave & 7 & $\checkmark$ & $\checkmark$ & $\checkmark$ & $\checkmark$ & & $\checkmark$ & $\checkmark$ & & \\
\hline & KhaoToNgaiGeologicalTimeBoundary & 5 & $\checkmark$ & $\checkmark$ & $\checkmark$ & & & $\checkmark$ & $\checkmark$ & & \\
\hline & Khao Noi Rock Succession & 5 & $\checkmark$ & $\checkmark$ & $\checkmark$ & & & $\checkmark$ & $\checkmark$ & & \\
\hline & Prasat Hin Punyod & 4 & $\checkmark$ & $\checkmark$ & & $\checkmark$ & & $\checkmark$ & $\checkmark$ & & \\
\hline & Wang Sai Thong Waterfall & 4 & $\checkmark$ & $\checkmark$ & & & & $\checkmark$ & $\checkmark$ & & $\checkmark$ \\
\hline & Lidi Lek Island & 4 & $\checkmark$ & $\checkmark$ & & & $\checkmark$ & $\checkmark$ & $\checkmark$ & & \\
\hline & Khao Daeng Nautiloid & 3 & $\checkmark$ & $\checkmark$ & & & & $\checkmark$ & $\checkmark$ & & \\
\hline & Thung Samet & 3 & $\checkmark$ & $\checkmark$ & & & & $\checkmark$ & $\checkmark$ & & \\
\hline & Tharae Stromatolite Lapies & 3 & $\checkmark$ & $\checkmark$ & & & & $\checkmark$ & $\checkmark$ & & \\
\hline & \multicolumn{11}{|c|}{ No signage system: Khuan Thung Type Section, } \\
\hline \multirow[t]{2}{*}{ Mueang Satun } & Hin Ngam Island & 4 & \begin{tabular}{l|l|l|}
$\checkmark$ & $\checkmark$
\end{tabular} & $\checkmark$ & $\checkmark$ & & $\checkmark$ & $\checkmark$ & $\checkmark$ & $\checkmark$ & \\
\hline & \multicolumn{11}{|c|}{$\begin{array}{l}\text { No on-site survey / Contain signage system: Mo Lae Bay, Son Bay } \\
\text { No on-site survey / No signage system: Pramong Beach Granite } \\
\text { No signage system: Khai Islet, Malaka Fomation }\end{array}$} \\
\hline
\end{tabular}

Findings in Signage Systems

Satun UNESCO Global Geopark uses a variety of meaningful signs to create awareness among visitors. According to the 
on-site survey, the signs can be categorized into 4 groups: Satun Geopark map \& information, geosite map \& information, geosite spot information, and precautions. The signage systems across geosites, especially map and information signs, show the consistency in their sizes, forms, and design layouts. However, there are very few signs to inform visitors about their safety. Even though Satun geopark contains many geosites in islands or coastal locations, a sign showing evacuation route in case of severe storm or tsunami cannot be found in such area.

In terms of content, there are geosite signs that present local information specific to each geosites as well as geopark signs that inform visitors about Satun UNESCO Global Geopark information. Both geopark signs and main geosite signs locates alongside at the site entrance. The content in a geopark sign usually contains an overall geopark map, history and background of Satun UNESCO Global Geopark, and geopark contact information. Similarly, the content in a geosite sign contains a site-specific information like a local map with nearby geosites, distinctive characteristics such as geological rock layers or specific fossils discovered in the area, precautions when entering the site, and geosite contact information. In popular geosites, there are also supplementary signs giving more details at some interesting spots. In addition, these geosites normally offer QR code signs for visitors to view extra contents like video or to visit the main website of Satun UNESCO Global Geopark for more educational contents. Most of the signs are in Thai and English, except in Hin Ngam Island where Chinese language is also included. The summary of sign content is shown in Table 3.

For sign materials, all geosites use thick steel which is durable in tropical monsoon climate in the south of Thailand. Illustrated in Figure 2, signboards come in two dimensions: 1) a large 300 × 200 square centimeters to present an overall map and information of Satun UNESCO Global Geopark and 2) a small $80 \times 60$ square centimeters to present map and information of a geosite. The number of signs installed on each geosite, as presented in Table 3, varies according to its geological importance and tourism popularity. In terms of design and layout, the signage systems in all geosites were created in the same direction. The design elements that communicate the geopark identities are mainly the logo of Satun UNESCO Global Geopark, the theme color of blue shades and photographs of iconic geosites.
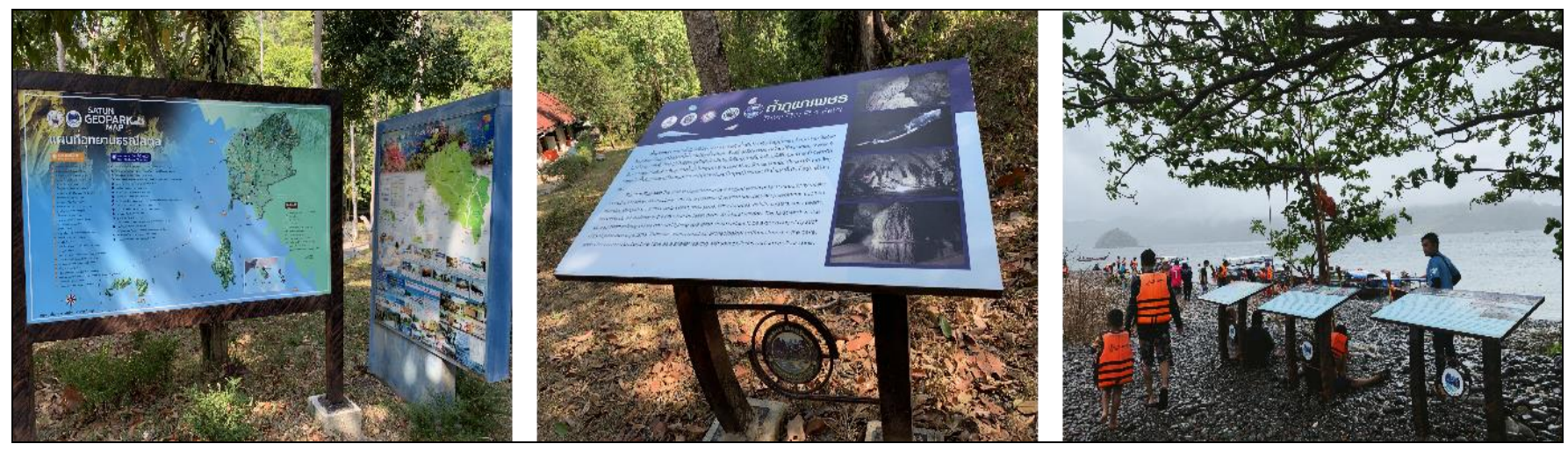

Figure 2. On-site signage system in a geosite normally consists of (left) geopark map \& information,

(middle) geosite map \& information, and (right) geosite spot information

\section{Insights from Community Leaders}

According to the interviews with community leaders, the Chief Executive of Thung Wa SAO commented on the development of identity communication for 2022 UNESCO revalidation of the global geopark. He suggested the creation of mascots to communicate geosite identities for tourist awareness. By combining the strengths of each district with storytelling, the mascots may add an extra touch by providing an informal attention and natural persuasion to geopark visitors, especially for kids. Moreover, the Deputy Chief Administrator of Palm Pattana SAO advised to use a variety of communication channels, both on-line and off-line, such as web sites, pamphlets, posters, and banners.

He focused on content management, especially on how to present the content in simple and fun style as well as how to adapt an academic issue to be more enjoyable. This may help tourists understand the content easier. He also mentioned about on-site learning for visitors by using more illustrations or visualizations with suitable levels of language for each tourist group. Additionally, the Deputy Director of Satun Geopark gave an idea on how to digest geological information and use storytelling techniques to motivate and inspire audiences. He also discussed about new technology that supports storytelling to attract tourists to the geosites. For the tourism communities, community enterprises and tour guides, they gave opinions that knowledge in marine fossil classification should be educated to all visitors. With the help of technology to communicate the information, many tourists may realize the value of geological tourism more easily.

\section{DISCUSSIONS}

On-site signage system in Satun Geopark provides information of the geosites as well as knowledge in geology in the area. Without signage system, visitors may lose interest in the visiting site and miss a good opportunity to learn from their experience in the actual location. According to our survey, some geosites are still lacking signage system in their area and this may create problems for tourism in a long run. A mascot design as a mean to convey tourism identity is another tool for tourism identity communication. A cartoon character is more universal, less cultural or language barrier, and can be used in a variety of ways (Van Ginhoven, 2019). The existing signage systems can be extended using the mascot without creating a new sign. Moreover, the mascot can be digitalized and expands its usages into cyber world, such as a character in a website, 
a sticker in messenger application etc. In addition, the mascot may act as the tourism ambassador in souvenirs or collecting. More value can be added to the character and this will benefit the local community in the geosite area. In terms of storytelling, a well-designed cartoon character gives a human touch to audiences, especially to children of any nationality. It is a helpful mean to communicate more difficult information through visual illustrations using the mascot character.

\section{Design of Tourism Identity for Satun UNESCO Global Geopark}

From the finding process of tourism identities, data from the in-depth interviews and on-site surveys of signage systems in geosites were analyzed and used as the guideline to design tourism identities for Satun UNESCO Global Geopark. The concept of identity mascots to communicate the unique characteristics of iconic geosites in each district was chosen as brand personality (Satyagraha and Mahatmi, 2018). This group of mascots was designed to convey key identities of the geopark to target visitors and to create identity awareness to draw public attention to the geosites.

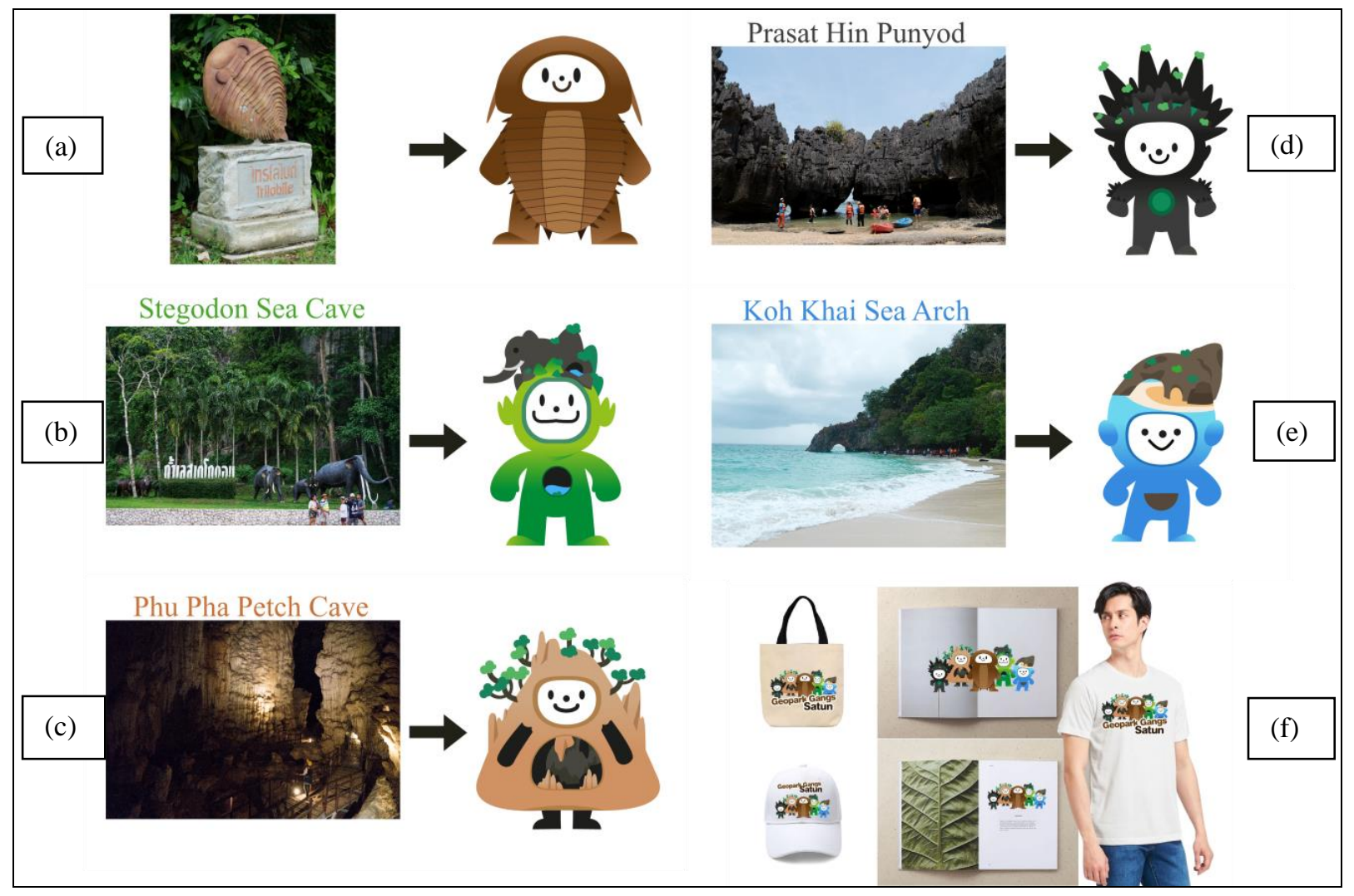

Figure 3. Design of Geopark Gang, a group of five mascots $(\mathrm{a}-\mathrm{e})$ representing Satun Geopark identities, and (f) samples of Geopark Gangs merchandise. [photos by NANTAKAT B., May \& December 2019]

The character design concept is to mimic unique appearances of the geosite and reduce its details until acquiring only the form that matters. This imitated icon is positioned on the top of the mascot's head. Each mascot is assigned different colors that is derived from the color tone in the actual location. The coloring differentiates the character's personality and builds identity awareness to the actual geosite. Under the concept of Geopark Gang, five cartoon characters were created as a group of close friends, each with distinct personalities and appearances. Five members in Geopark Gang consist of one character representing the geoparks itself and the other four characters representing the iconic geosites in each four districts of the geopark. The selection criteria are outstanding characteristics and high potential as tourist attractions. The character design of each mascots comes from the following identities:

- Trilobite (Figure 3a):

The first character represents Satun Geopark as a whole with Trilobite, the very first fossils found in the area and the beginning of Satun Geopark. The mascot body mimics the shape of the Trilobite in brown color.

- Stegodon Sea Cave in Thung Wa District (Figure 3b):

This geosite is renowned as a sea cave with the fossils of elephants found inside. Hence, the Stegodon elephant in dark green is chosen for the storytelling with the backdrop of evergreen forest.

- Phu Pha Petch Cave in Manang District (Figure 3c):

This geosite is famous for beautiful stalactites and stalagmites inside the cave. Therefore, the shape of upside-down stalactites and stalagmites are used in the narrative.

- Prasat Hin Punyod in La-ngu District (Figure 3d):

This geosite features a limestone peak with thousands of castle-like tip as suggested by its name. This feature inspires the design of the mascot's head with a plenty of long, pointed tips in a dark green tone.

- Koh Khai Sea Arch in Mueang Satun District (Figure 3e): 
The design imitates the appearance of corroded stone with penetrating holes, along with the white-sand beach and clear blue sea reflected in the character coloring.

\section{CONCLUSION}

Signage system on a tourist site is a communication channel to provide essential information for visitors. It is a common place to communicate identities of the tourist site to create site awareness and draw public attention. Tourism identity is a unique characteristic of a particular tourist site which creates values and appeals to visitors. According to the interviews with community leaders and the surveys of on-site signage system, the analysis leads to the use of identity communication as a tool to promote and publicize the tourism in the community. Using a character mascot to convey the identities of a tourism site is another approach in tourism identity communication. Storytelling through mascot design using tourism identity help create recognition and connection to the tourism site. The communication channels can be expanded through a variety of usages in mascot or character design, ranging from a regular symbol in on-site signage system to digital assets in on-line applications. This will draw more public attention as well as generate income to the community.

\section{REFERENCES}

Calori, C., \& Vanden-Eynden, D. (2015). Signage and wayfinding design: a complete guide to creating environmental graphic design systems. John Wiley \& Sons.

Chaiala, P., \& Ruengroj, S. (2016). Identity Study and Meaning Communication for Promoting Tourism in Ban Srabua. Rajabhat Mahasarakham University Journal, 10(3), 121-136 (in Thailand).

Chantub, R., \& Pocharee, L. (2016). Tourism Identity Factors Affecting the Success of Tourism Management in Chang Ta Kang Village, Surin Province. WMS Journal of Management, 5(1), 48-59 (in Thailand).

Dhamabutra, P. (2019). Approaches for Cultural Tourism 4.0 Brand Development in Bangkokyai Community, Bangkok. Sisaket Rajabhat University Journal, 13(2), 83-101 (in Thailand).

Górska-zabielska, M., \& Zabielski, R. (2019). Stone in an Urban Space - Its Potential To Promote Geotourism. GeoJournal of Tourism and Geosites, 26(3), 1033-1045. https://doi.org/10.30892/gtg.26327-415

Henriques, M.H., \& Brilha, J. (2017). UNESCO Global Geoparks: A strategy towards global understanding and sustainability. Episodes, 40(4), 349-355. https://doi.org/10.18814/epiiugs/2017/v40i4/017036

Mastika, I.K., \& Nimran, U. (2020). Destination branding model of an ecological tourism village in Bali, Indonesia. Geojournal of Tourism and Geosites, 31(3), 1068-1074. https://doi.org/10.30892/gtg.31319-542

Mohd Yusof, M.F., Ismail, H.N., \& Ahmad, G. (2019). Branding Langkawi Island As a Geopark Destination. International Journal of Built Environment and Sustainability, 6(1-2), 7-14. https://doi.org/10.11113/ijbes.v6.n1-2.377

Ongkrutraksa, W. (2015). International natural disaster communications : an exploratory study of signage for tsunami, earth quake and fl ood in Japan and Thailand Worawan. Journalism \& Media, Nihon University, 8(March 2015), 7-19.

Pásková, M., \& Zelenka, J. (2018). Sustainability Management of Unesco Global Geoparks. Sustainable Geoscience and Geotourism, 2, 4464. https://doi.org/10.18052/www.scipress.com/sgg.2.44

Pera, R. (2017). Empowering the new traveller: storytelling as a co-creative behaviour in tourism. Current Issues in Tourism, 20(4), 331338. https://doi.org/10.1080/13683500.2014.982520

Ruban, D.A. (2018). Karst as Important Resource for Geopark-Based Tourism: Current State and Biases. Resources, 7(4). https://doi.org/10.3390/resources7040082

Satyagraha, A., \& Mahatmi, N. (2018). Study of Mascot Design Character As Part Of City Branding: Malang City. ULTIMART Jurnal Komunikasi Visual, 11(2). https://doi.org/10.31937/ultimart.v11i2.1019

Soltani, A., Pieters, J., Young, J., \& Sun, Z. (2018). Exploring city branding strategies and their impacts on local tourism success, the case study of Kumamoto Prefecture, Japan. Asia Pacific Journal of Tourism Research, 23(2), 158-169. https://doi.org/10. 1080/10941665.2017.1410195

Stoffelen, A. (2020). Where is the community in geoparks? A systematic literature review and call for attention to the societal embedding of geoparks. February 2019, 97-104. https://doi.org/10.1111/area.12549

Strydom, A.J., Mangope, D., \& Henama, U.S. (2019). Making community-based tourism sustainable: Evidence from the Free State province, South Africa. Geojournal of Tourism and Geosites, 24(1), 7-18. https://doi.org/10.30892/gtg.24101-338

Thungprue, N., Jintsakul, P., Hattha, K., Wongwanichr, T., Songtham, W., Thongnueakhaeng, P., Nutatheera, T., \& Warawannasongkhram, R. (2015). Satun Geopark Administration Master Plan (Final Report). Department of Mineral Resources, Thailand.

Tölkes, C. (2018). Sustainability communication in tourism - A literature review. Tourism Management Perspectives, 27(September 2017), 10-21. https://doi.org/10.1016/j.tmp.2018.04.002

Van Ginhoven, S.R. (2019). Attracting International Tourists through Mascot Awareness. Ritsumeikan Asia Pacific University.

Wolniewicz, P. (2019). Bringing the History of the Earth to the Public by Using Storytelling and Fossils from Decorative Stones of the City of Poznań, Poland. Geoheritage, 11(4), 1827-1837. https://doi.org/10.1007/s12371-019-00400-2

Worrachaddejchai, D. (2020). Southern operators keen to promote beach-friendly tourism. Bangkok Post, 13.01.2020, 13. https://www.bangkokpost.com/ business/1834449/southern-operators-keen-to-promote-beach-friendly-tourism

*** Tourism Authority of Thailand. (2020). 60 Years of Pride The Journey of Thailand's Sustainable Tourism. Promotional Material Production Division, Marketing Services Department, Tourism Authority of Thailand (TAT). https://www.amazingthailandebook. com/files/book241/ae21c2bb44265502c06 c73e2bceb21931583988577344.pdf

*** UNESCO. (n.d.). Operational Guidelines for UNESCO Global Geoparks. http://www.unesco.org/new/fileadmin/MULTIMEDIA/ HQ/SC/pdf/IGGPUGG StatutesGuidelinesEN.pdf 